\title{
HUBUNGAN KEMAMPUAN SELF-DIRECTED LEARNING DAN PROBLEM SOLVING SISWA SMP MELALUI PEMBELAJARAN BERBASIS MASALAH
}

\author{
Asep Irvan Irvani \\ Jurusan Pendidikan Fisika, FPIK Universitas Garut \\ Email: airvanirvan@gmail.com
}

\begin{abstract}
ABSTRAK
Telah dilakukan penelitian yang bertujuan untuk melihat hubungan kemampuan self-directed learning dengan kemampuan problem solving siswa melalui pembelajaran berbasis masalah pada materi pemantulan cahaya. Metode penelitian yang digunakan adalah metode penelitian deskriptif dengan jenis penelitian korelasi yang dilaksanakan di kelas VIII di salah satu SMP negeri di kota Cimahi pada tahun pelajaran 2012/2013. Pengumpulan data dilakukan dengan menggunakan angket skala bertingkat untuk kemampuan self-directed learning, postest uraian terbuka untuk kemampuan problem solving, dan lembar observasi untuk keterlaksanaan rencana pembelajaran. Berdasarkan hasil analisis data, setelah dilakukan pembelajaran berbasis masalah, diperoleh ratarata kemampuan self-directed learning siswa dalam kategori sedang. Untuk kemampuan problem solving didapatkan rata-rata siswa dalam kategori sedang. Hasil perhitungan korelasi didapatkan nilai $\mathrm{r}$ sebesar 0,749 dengan kategori tinggi. Kemampuan self-directed learning berkontribusi sebesar 56,05\% terhadap kemampuan problem solving siswa. Disimpulkan bahwa terdapat hubungan positif yang signifikan antara kemampuan self directed learning dengan kemampuan problem solving siswa SMP pada pembelajaran berbasis masalah pada materi pemantulan cahaya

Kata kunci: kemampuan self directed learning, kemampuan problem solving, pembelajaran berbasis masalah
\end{abstract}

Received: 14 Desember 2018 ; Accepted: 1 Februari 2019 ; Published: 4 Februari 2019 


\section{PENDAHULUAN}

Pendidikan formal di sekolah memiliki peran penting dalam pembentukan karakter anak yang inisiatif. Kemampuan inisiatif ini merupakan kemampuan self-directing learning (SDL). Selfdirecting learning ini menurut Knowles (Bangun,2011:61) adalah suatu proses di mana sebuah individu mengambil inisiatif, dengan atau tanpa bantuan orang lain, dan proses dalam selfdirecting learning ini dilakukan dengan menyadari kebutuhan sendiri dalam belajar, mengatur tujuan pribadi, membuat keputusan pada sumber dan strategi belajar dan menilai hasil.

Untuk meningkatkan kemampuan selfdirecting learning siswa dapat dilakukan dengan pembelajaran berbasis masalah (PBL). Menurut Barrows \& Tamblyn (Hung, 2008:118) pembelajaran berbasis masalah bertujuan untuk meningkatkan aplikasi pengetahuan siswa, kemampuan menyelesaikan masalah, kemampuan berpikir kritis, dan kemampuan selfdirecting learning. Oleh karena itu salah satu cara untuk melatihkan siswa agar memiliki kemampuan self-directing learning salah satunya dengan melakukan metode pembelajaran Problem Based Learning (PBL).

Selain kemampuan self-directed learning, ada kemampuan lain yang tak kalah penting dalam memenuhi tuntutan zaman saat ini. Kemampuan itu adalah kemampuan memecahkan masalah. Setiap orang pasti merasakan bahwa semakin lama semakin banyak persoalan yang muncul di kehidupan ini. Apalagi di kehidupan yang akan dijalani oleh siswa pada masa yang akan datang. Akan banyak sekali permasalahan baru yang mungkin belum pernah terjadi sebelumnya. Oleh karena itu sangat penting sekali melatihkan kemampuan problem solving terhadap anak pada usia dini.

$\begin{array}{ccc}\text { Hung (2008:118) menyatakan bahwa } & \text { mongan } \\ \text { pembelajaran dengan menggunakan model } \\ \text { Problem Based Learning (PBL) bertujuan untuk }\end{array}$

meningkatkan pengetahuan aplikasi siswa, keterampilan problem solving, kemampuan berpikir kritis dan kemampuan self-directed learning. Artinya kemampuan self-directed learning dan kemampuan problem solving dapat ditingkatkan melalui pembelajaran berbasis masalah (PBL)

\section{METODE PENELITIAN}

Menurut Gibbons (Chee, 2011:12), SelfDirected Learning (SDL) adalah peningkatan pengetahuan, keahlian, prestasi dan mengembangkan diri dimana individu menggunakan banyak metode dalam banyak situasi dalam setiap waktu. Menurut Isma (2010), self-directed learning adalah metode yang digunakan siswa untuk mengontrol tujuan belajar dan cara belajar. Knowles (Bangun, 2011:61) menambahkan bahwa self-directed learning adalah sebuah proses dimana sebuah dimana individu mengambil inisiatif, dengan atau tanpa bantuan orang lain, dan proses dalam selfdirected learning ini dilakukan dengan menyadari kebutuhan sendiri dalam belajar, mengatur tujuan pribadi, membuat keputusan pada sumber dan strategi belajar dan menilai hasil. Kemampuan self-directed learning berarti kemampuan siswa dalam mengatur tujuan dan cara belajarnya secara mandiri dan inisiatif untuk meningkatkan kemampuan dan prestasi belajarnya.

Problem solving adalah suatu proses bagi siswa menemukan panduan antara sebelumnya yang sudah dipelajari untuk diterapkan dalam memperoleh pemecahan bagi situasi baru (Gagne dalam Rahman, 2009). Davis dan Alexander (Hardianty, 2011:8) menyatakan bahwa problem solving merupakan proses yang sangat kompleks dengan melibatkan beberapa dasar aktivitas psikologi. Dari beberapa pengertian tersebut, dapat disimpulkan bahwa probem solving merupakan rangkaian kegiatan yang dilakukan siswa secara sistematis dalam menyusun pengetahuan dan keterampilan yang telah dimilikinya untuk menyelesaikan suatu permasalahan. 
Kemampuan problem solving adalah kemampuan individu dalam menggunakan pengetahuan dan cara berpikir logisnya untuk menganalisis informasi dari suatu permasalahan, menyusun alternatif-alternatif pemecahan masalah yang mungkin dikakukan, dan memilih pemecahan masalah yang paling efektif. Bransford dan Stein (Nitko dan Brookhart, 2011:232) merumuskan kemampuan problem solving ke dalam lima tahap, yaitu:

a. mengidentifikasi masalah,

b. mendefinisikan dan merumuskan masalah,

c. mengeksplorasi strategi pemecahan masalah,

d. melaksanakan strategi pemecahan masalah, dan

e. mengecek kembali hasil yang diperoleh dan mengevaluasi efek dari strategi pemecahan masalah yang telah diambil.

Pembelajaran berbasis masalah atau Problem Based Learning (PBL) adalah suatu model pembelajaran yang melibatkan siswa untuk memecahkan suatu masalah melalui tahap-tahap metode ilmiah sehingga siswa dapat mempelajari pengetahuan yang berhubungan dengan masalah tersebut dan sekaligus memiliki keterampilan untuk memecahkan maslah. (Ward, 2002; Stepien, et al, 1993 dalam Latifah, 2012). Model pembelajaran pada penelitian ini meliputi tahaptahap: 1) pengorientasian masalah, 2) pengorganisasian untuk belajar, 3) membimbing untuk pengelidikan, 4) mengembangkan dan menyajikan hasil karya, dan 5) menganalisis dan mengevaluasi pemecahan masalah.

Desain masalah dalam Problem Based Learning (PBL) bisa menjadi salah satu hal yang menentukan efektivitas PBL. Siswa tidak memperoleh akuisisi pengetahuan dasar yang cukup. Menurut Hung, Baley, \& Jonassen (Hung, 2008) bahwa banyak kritikus yang berpendapat bahwa masalah PBL menuntut siswa mempertimbangkan hanya konten yang terbatas untuk mengembangkan pemahaman yang lebih dalam mengenai suatu topik. Cara tersebut kemungkinan dapat membatasi paparan siswa untuk memahami konten yang lebih luas sesuai dengan kurikulum, tetapi secara tidak langsung berkaitan langsung dengan masalah yang sedang diselidiki. Di sisi yang lain, situasi sebaliknya bisa menjadi kemungkinan penyebab siswa kurang dalam mendapat pengetahuan dasar. Kemungkinan ini yakni masalah PBL yang ada menuntut siswa untuk menyelidiki dan mempelajari melebihi informasi yang bukan menjadi bagian dari isi pembelajaran namun dibutuhkan untuk memecahkan masalah.

Model desain masalah 3C3R PBL terdiri dari dua komponen, yaitu komponen inti dan komponen pengolahan. Komponen inti meliputi content (konten), context (konteks) dan connection (koneksi), 3C berhubungan dengan isi/ konsep pembelajaran dalam PBL. Komponen pengolahan, 3R, meliputi researching (meneliti), reasoning (penalaran), dan reflection (mencerminkan), yang mendukung proses kognitif pemecahan masalah self-directed learning.

Metode penelitian yang digunakan dalam penelitian ini adalah metode deskriptif. Penelitian deskriptif adalah penelitian yang dimaksudkan untuk menyelidiki keadaan, kondisi atau hal lainlain, yang hasilnya dipaparkan dalam bentuk laporan penelitian (Arikunto, 2010:3). Arikunto menjelaskan bahwa bahwa penelitian deskriptif bukan hanya satu jenis kegiatan saja tetapi sekurang-kurangnya ada 5 (lima) jenis, yaitu (a) penelitian deskriptif murni atau survei (b) penelitian korelasi, (c) penelitian komparasi, (d) penelitian penelusuran (tracer Study) dan (a) penelitian evaluasi.

Secara khusus, penelitian yang dilakukan menggunakan metode penelitian deskriptif dengan jenis penelitian korelasi. Penelitian korelasi atau penelitian korelasional adalah penelitian yang dilakukan oleh peneliti untuk mengetahui tingkat hubungan antara dua variabel atau lebih, tanpa melakukan perubahan, tambahan atau manipulasi terhadap data yang memang sudah ada (Arikunto, 2010:4). Aspek utama yang diteliti dalam penelitian ini adalah hubungan antara kemampuan self-directed learning dengan kemampuan problem solving yang dimiliki siswa melalui pembelajaran 
berbasis masalah yang menggunakan desain masalah 3C3R.

Pembelajaran dilaksanakan sebanyak dua kali pertemuan pada Mei 2013. Populasi pada penelitian ini adalah kelas VIII salah satu SMP Negeri di kota Cimahi. Ada dua jenis instrumen yang digunakan dalam penelitian ini, yaitu instrumen nontest dan test. Instrumen nontest berupa angket skala bertingkat digunakan untuk mengukur kemampuan sel-directed learning siswa. Instrumen Test berupa soal uraian terbuka sebanyak 18 pertanyaan dengan tiga masalah mengenai pemantulan cahaya, digunakan untuk mengukur kemampuan problem solving siswa. Kedua instrumen telah di-judgement dan diujicobakan terlebih dahulu sebelum diberikan kepada siswa pada akhir pembelajaran.

Untuk melihat bagaimana hubungan kemampuan sel-directed learning dan kemampuan problem solving siswa dihitung nilai koefisien regresi. Koefisien regresi menunjukan seberapa kuat hubungan kedua koefisien tersebut.

\section{HASIL DAN PEMBAHASAN}

Berdasarkan hasil perhitungan, diperoleh nilai korelasi rhitung sebesar 0,749. Sedangkan pada tabel untuk $\mathrm{N}=28$ diperoleh nilai rtabel sebesar 0,374. Karena nilai rhitung lebih besar dibandingkan dengan rtabel, maka dapat disimpulkan bahwa terdapat hubungan yang positif (searah) antara kemampuan self-directed learning dengan kemampuan problem solving siswa. Dan dilihat dari nilai koefisien korelasi yang diperoleh, tingkat hubungan kedua kemampuan tersebut termasuk dalam kategori kuat. Hal ini terlihat pada saat proses pembelajaran berlangsung. Siswa yang cenderung aktif terlibat dalam kegiatan pembelajaran ternyata memiliki nilai kemampuan self-directed learning yang tinggi dan juga memiliki nilai kemampuan problem solving yang tinggi. Sesuai dengan apa yang dikatakan oleh Barrows \& Tamblyn (Hung, 2008:118) bahwa pembelajaran berbasis masalah salah satunya bertujuan untuk meningkatkan kemampuan menyelesaikan masalah, dan kemampuan self-directing learning.
Berdasarkan hasil perhitungan didapatkan nilai thitung sebesar 5,758 dan ttabel sebesar 1,706 dengan tingkat kesalahan 0,05. Karena thitung > ttabel maka dapat disimpulkan bahwa terdapat signifikansi hubungan antara kemampuan self-directed learning dengan kemampuan problem solving siswa.

Untuk menghitung kontribusi dari kemampuan self-directed learning terhadap kemampuan problem solving siswa, digunakan persamaan koefisien determiniasi. Koefisien determiniasi adalah kuadrat dari koefisien korelasi, dan berdasarkan nilai koefisien korelasi diperoleh nilai koefisien determiniasi sebesar $56,05 \%$. Ini artinya varian dari variabel kemampuan problem solving, 56,05\% ditentukan oleh varian variabel kemampuan self-directed learning. Atau dengan kata lain kemampuan selfdirected learning berkontribusi sebesar 56,05\% terhadap kemampuan problem solving siswa.

Dari hasil yang diperoleh, kontribusi kemampuan SDL siswa hanya termasuk dalam kategori sedang terhadap kemampuan problem solving siswa. Hal ini menunjukan bahwa siswa belum bisa sepenuhnya belajar secara mandiri atau menjadi self-directed learner yang baik. Siswa pada usia remaja ini masih sangat membutuhkan bimbingan guru untuk mengatur strategi dan kegiatan belajarnya.

Kemampuan siswa dalam memecahkan masalah pemantulan cahaya yang terjadi dalam kehidupan sehari-hari menuntut siswa untuk meramu pengetahuan dan mengaplikasikannya dalam kehidupan sehari-hari. Semakin banyak pengetahuan yang dimiliki maka semakin mudah siswa memecahkan masalah. Banyaknya pengetahuan siswa dapat diperoleh dengan kemampuan self-directed learning yang tinggi, karena dengan kemampuan self-directed learning yang tinggi membuat siswa mau mencari pengetahuan secara mandiri dan mampu menentukan pengetahuan apa saja yang diperlukan dalam kegiatan belajarnya..

\section{KESIMPULAN}

Berdasarkan hasil penelitian yang dilakukan di salah satu SMP negeri di kota Cimahi mengenai 
hubungan kemampuan self-directed learning dan kemampuan problem solving siswa melalui pembelajaran berbasis masalah, maka dapat ditarik beberapa kesimpulan bahwa terdapat hubungan positif yang signifikan antara kemampuan self-directed learning dengan kemampuan problem solving siswa SMP pada pembelajaran berbasis masalah pada materi pemantulan cahaya.

\section{DAFTAR PUSTAKA}

Abbas, N. (2000) Penerapan Model Pembelajaran Berdasarkan Masalah (problem based instruction) dalam Pembelajaran Matematika di SMA, [Online] tersedia : http://arimath.weebly.com/uploads/1/0/4/ 2/10425109/contoh skripsi ekspriment.pdf (tanggal akses 8 Februari 2013)

Akbar, D.M. (2012). Rancangan Penerapan Model Pembelajaran Problem Based Learning pada Mata Pelajaran Elektronika Digital di SMKN 4 Bandung. Skripsi Jurusan Pendidikan Teknik Elektro UPI : Tidak diterbitkan.

Arikunto, S. (2012). Dasar-dasar Evaluasi Pendidikan Edisi 2. Jakarta: Bumi Aksara.

Arikunto, S. (2010). Prosedur Penelitian. Jakarta: PT Rineka Cipta.

Arikunto, S. (2009). Dasar-dasar Evaluasi Pendidikan. Jakarta: Bumi Aksara.

Chee, T.S. et al. (2011). Self-Derected Learning Alt ICT: Theory, Practice and Assesment. Singapore: Ministry of Education.

Bangun, G.E.S. (2011). Perbedaan Self Directed Learning Siswa Sekolah Menengah Atas dan Sekolah menengah Kejuruan di Yayasan Dharma Bakti Medan.Skripsi Jurusan Psikologi USU : Tidak diterbitkan.

Dahar, R.W. (1996). Teori-Teori Belajar. Jakarta: Erlangga.

Hardianty, N. (2011). Analisis Kemampuan Problem Solving Siswa SMP dalam Pembelajaran Pendidikan Teknologi Dasar. Skripsi Jurusan Pendidikan Fisika UPI : Tidak diterbitkan.

Hung, W. (2008). The 9-step problem design process for problem-based learning:
Application of the 3C3R model. Educational Research Review 4 tahun 2009 118-141.

Kafaah, A.S. (2012). Kemampuan Reflektif Mahasiswa dalam Penyuluhan PKK sebagai hasil Penerapan Model Problem Based Learning(PBL). Skripsi Jurusan Pendidikan Kesejahteraan Keluarga UPI : Tidak diterbitkan.

Latifah, B. (2012) Penerapan Model Pembelajaran Berbasis Masalah untuk Meningkatkan Penguasaan Konsep Elastisitas Siswa SMA. Skripsi Jurusan Pendidikan Fisika UPI : Tidak diterbitkan.

Nitko, A.J dan Brookhart, S,M (2011). Educational Assessment of Students (6th Edition). Boston: Pearson Education.

Panggabean, P.L. (2001). Statistika Dasar. Bandung: Jurusan Pendidikan Fisika FPMIPA UPI.

Panggabean, P.L. (1989). Penelitian Pendidikan. Bandung: Jurusan Pendidikan Fisika FPMIPA UPI.

Panggabean, P.L. (1989). Konstribusi Relatif Sikap Siswa SMP pada Bimbingan Konseling Terhadap Prestasi Belajar Fisika. Tesis Magister pada Sekolah Pascasarjana IKIP Bandung: tidak diterbitkan.

Rahman, D. (2009). Upaya Meningkatkan Kemampuan Memecahkan Masalah dengan Menggunakan Model Pembelajaran Pemecahan Masalah. Skripsi Jurusan Pendidikan Fisika UPI : Tidak diterbitkan.

Riduwan. (2010). Dasar-dasar Statistika. Bandung: Alfabeta.

Saefullah, A. (2012). Hubungan Antara Sikap Kemandirian Belajar dan Prestasi Belajar Siswa Kelas X Pada Pembelajaran Fisika Berbasis Portofolio. Skripsi Jurusan Pendidikan Fisika: Tidak diterbitkan.

Sudjana. (2009). Penilaian Hasil Proses Belajar Mengajar. Bandung: PT Remaja Rosdakarya.

Sudjana. (2005). Metoda Statistika. Bandung : Tarsito.

Widiaty, I. (2010). SDL (Self Directed Learning) Through e- Learning Based on e- Pedagogy Principals for Pre-Service Teacher in TVET. Proceedings of the 1stUPI International 
Conference on Technical and Vocational Education and Training Bandung, Indonesia, 10-11 November 2010.

Williamson. (2007). Development of a self-rating scale of self-directed learning. Nurse Researcher 14. Hlm 66-83. 